\title{
Labour Market Flexibility Relations and Social Cohesion in Spain 1980-2009
}

\author{
Teodoro Hernandez de Frutos' ${ }^{1}$ José Antonio Diaz Martínez², Neus Caparros Civera ${ }^{3}$ \\ ${ }^{1}$ Department of Sociology, Public University of Navarra, Pamplona, Spain \\ ${ }^{2}$ Department of Sociology, National University of Distance Education (UNED), Madrid, Spain \\ ${ }^{3}$ Department of Social Work and Law, Rioja University, Logroño, Spain \\ Email: theo@unavarra.es, jdiaz@poli.uned.es, caparros@unirioja.es
}

Received 29 September 2014; revised 16 November 2014; accepted 2 December 2014

Copyright (C) 2015 by authors and Scientific Research Publishing Inc.

This work is licensed under the Creative Commons Attribution International License (CC BY). http://creativecommons.org/licenses/by/4.0/

(c) (i) Open Access

\begin{abstract}
In this article the different phases social cohesion in Spain has passed through from 1980 to 2010 , which is analysed using time series based on developments within the work market and the area of social protection. By observing unemployment rates taken from the survey of the working population a clear change of tendency can be noted in the year 1985, when as a result of the first work market reform, temporary employment was introduced, and in the years 1994, 2001 and 2010. The rates of temporary employment demonstrate the plateau produced from 1992 to 2006 . As regards the area of social protection, we use the time series SEEPROSS of retirement pensions with the six important work market reforms of 1985, 1990, 1995, 2002, 2007 and 2010. Health with the inflection points at 1984, 1990 and 2003 when the transfers to the autonomous communities are finalized and of benefits for unemployment, family, survivors, social exclusion and housing. In a comparison with neighbouring countries a important distance can be observed as regards developments in the work markets, while the position is more discrete in the area o social market.
\end{abstract}

\section{Keywords}

Social Cohesion, Labour Market, Social Market, Crisis, Unemployment, Temporary Jobs, Old Age, Sickness, Family, Survivors, Social Exclusion, Housing

\section{Introduction}

Industrial relations institutions in Spain have undergone significant transformations as a result of the financial and sovereign debt crises; austerity packages and structural reforms have been introduced in order to enforce internal devaluation and reduce public debt and unemployment by contradictory forces (Molina, 2014). Unions in 
Spain have been late to develop bargaining capacities to improve working conditions of temporary workers fixed term employment, temporary agency employment, wage limited part time contracts and legal minima covering regular open-ended employment contracts. Until 1984 employers were restricted by legal limits on their use, and unions attempted to maintain restrictions preventing regular worker being replaced by temporary worker but the widespread deregulation of temporary agency and fixed-term employment have been more pronounced (Shire, Schönauer, Valverde, \& Mottweiler, 2009). Anyway employment relations and institutions varying across contexts, flexibility, pay and working time are mediated and constructed in various ways according to national systems of regulation and tradition of struggle and meaning (Connolly, Marino, \& Lucio, 2014).

Few studies have looked at social cohesion in Spain even though it is a concept frequently used by trade unions, government and employers. Nevertheless, there have been some important papers on the subject, from the perspective of the labour market. Another contribution matches social protection with social cohesion based on ESSPROS indicators (Hernández de Frutos, 2003). And from the perspective of integration between native population and immigrants, several authors recently highlighted the difficulties that the unsolved issue of immigration poses for good social cohesion in Spain. One of the first problems we come across when studying social cohesion in this country is that it is a very elastic concept to define and a very fuzzy concept to measure. The discrepancies that stem from this can be seen in the various uses (Easterly, Ritzer, \& Woolcock, 2006) given to the concept by international organizations (European Council, 2008; OECD, 1997).

Globalization is considered to be one of the main external factors influencing social cohesion due to its repercussions on the economy, and its effects have multiplied over the last forty years with the use of information and communication technologies (James, 2010; Stern, 2009). The speed and transparency with which the international market functions because of the internet means that the position a country holds on the world stage can rapidly change, thereby affecting its exports, which in turn affects its labour market, causing imbalances in its working population (Eraydin, 2008). The countries most exposed to upheaval are naturally those whose exports are the least technologically complex. Inequality when it comes to sharing the benefits has effects that spread through society as a whole and may lead to an increase in violence and crime and prevent representative democracy from functioning smoothly (Kawachi \& Kennedy, 1997). Furthermore, a country’s economy as measured by its labour market depends on its international competitiveness, which forces it to link economic performance (profits, surpluses, deficits) to the working population (salaries, working hours, holidays, promotion, seniority) (Shalendra, 2008; Standing, 2009).

Obviously the more competitive a country is and the more products it exports, the higher its economic profits will grow, accompanied by an increased demand for work, better employment opportunities and less social exclusion and poverty (Robertson, 2009). Seen in this light, Spain, a technologically average country despite its continuous efforts over the last few decades to improve its position as regards technological complexity, has at certain times been disastrously hit by big international crises that have affected its exports and therefore its labour market (Hernández de Frutos, 2009). Since the restoration of democracy, the unions had concerted with governments to project reforms of public administration, but very little change resulted. When the Spanish bubble burst, the socialist and conservative government introduced strong austerity measures breaking the social cohesion (Stoleroff, 2013).

\section{Social Cohesion through the Labour Market}

The starting point for a contemporary history of social cohesion in Spain from the perspective of the labour market can be found during the transition. The return of democracy brought about a feeling of togetherness that made most people forget the great inequalities and injustices they were leaving behind. However, this began to deteriorate after the 1975 crisis, which brought upheaval to industrialized countries including Spain, just emerging from Franco's era of autarky. The earliest public democratic actions aimed at ensuring social cohesion from the perspective of the labour market came with the Moncloa Pacts of 1977, the Workers' Statute of 1980 and the Employment Act, also in 1980. The first of these dealt with different aspects of labour relations such as employment contracts and the different forms they took (construction or services, temporary or casual, work experience, training, part-time, retirement substitution, substitution in a higher grade, new business launch). The second dealt with employment policy as a collection of decisions whose basic aim was to find a balance between supply and demand and protection for the unemployed, with priority courses of action aimed at increasing employment, setting up systems to prevent unemployment, increasing transparency in the labour market through information, guidance and professional training, and encouraging geographical and occupational mobility. 
Modifications to the Workers' Statute, which incidentally did not include civil servants, are the best mirror in which to see the ups and downs social cohesion has experienced. The Statute has undergone reforms large and small since its introduction, all of them focusing on the fragmentation of the labour force caused by unemployment and temporariness. Faced with very high unemployment figures in 1984 after two years in power, the Socialist government detected a large social divide and sought the solution through intervention in the labour market, there being almost complete consensus that this was too inflexible when it came to hiring. The basic intention was to "create the greatest number of jobs possible" for young people and unemployed workers following the European example and to aim to reduce employers' uncertainty regarding what they saw as a mismatch between the length of an employment contract and forecasts for future economic growth. The period of uncertainty was set at three years and therefore this was the duration established for new contracts.

The biggest change was made to Article 17 of the Workers' Statute which dealt with workers nearing retirement, workers with a diminished capacity for work and unemployed workers entering their first job. The modification consisted of a new "employment promotion contract” which could be given to any unemployed worker. This meant that temporary contracts no longer applied only to seasonal jobs but also to regular jobs, thereby reducing severance costs (Dolado, García, \& Jiméno, 2002) through what is called flexibility at the margin (Segura, Durán, Toharia, \& Bentolila, 1991). Once the worker had been in the job for three years with this contract, there were two options: either the worker who had been doing the job over this period was taken on permanently or nobody could be taken on to do the job (Dolado \& Jimeno, 2004). Employment contracts according to duration underwent a radical turnaround in a short period of time, with the clear preference for open-ended contracts changing into a preference for the opposite which involved virtually cost-free severance, leading to the start of a huge increase in temporary hirings. From here on, newly-signed open-ended contracts would account for less than $5 \%$ of the total. But unemployment, which reached record levels in 1985, fell steeply during the next five years, thereby validating the reform.

The effects of the reform were rapid and devastating for job security because temporariness gave rise to an excessive turnover of workers and unforeseen unemployment benefit claims. Between 1987 and 1990, the rate of temporariness among workers as a whole regardless of age increased steeply, rising from $18.1 \%$ to $30.3 \%$, and then fluctuated around the 30\% mark but never below it (CES, 1996). Differences from the rest of the population were notable because they grew year after year, bringing about a clear divide between age groups (Sánchez \& Delicado, 2007). A time of upheaval with sudden changes for social cohesion began at this point because periods of economic growth brought the creation of massive numbers of jobs, but periods of depression brought the destruction of massive numbers of jobs depending on how employers saw the immediate future.

A new reform was drafted just three years later, but the 1988 general strike in protest against the government's economic policy and youth employment plan delayed any attempt at change. In 1992 the amount spent on unemployment benefit brought about a drastic tightening of the rules, and in 1994, in view of the seriousness of the situation, a second important reform was carried out. This came in the form of the 10/1994 Act entitled "urgent measures for boosting employment", which again modified the types of contract contained in the Workers' Statute, this time without reaching an agreement with the unions. The main aim of this law, an aim that would condition the laws that followed, was to reduce temporariness because of the ever more obvious dual nature of work. It was clear that temporariness condemned workers to high turnover and meant companies could get away with not training their employees (Royuela \& Sanchis, 2010). The new measures were aimed mainly at young people and their entry into the labour market and included the elimination of the temporary employment promotion contract, which was earmarked for those over 45 and disabled workers. However, the most widelyused contracts, those which furthermore involved no severance or redundancy costs, remained unchanged. According to the figures for 1994, these were construction or services contracts (accounting for $47.83 \%$ of new contracts), temporary contracts (34.33\%) and part-time contracts (19.38\%).

At the same time temporary employment agencies and non-profit-making staff agencies were legalized. The reasons for dismissal involving indefinite contracts were modified to distinguish between individual and collective dismissals. The latter, which have taken on so much importance since then, were defined as those affecting in a period of 90 days at least $10 \%$ of the workforce or all the workforce of a company with less than 5 employees, thus giving rise to company redundancy plans (Bentolila, 1997). This reform can be linked to another clear social divide brought about by the increase in unemployment, which rose from $11.97 \%$ in 1990 to $24.12 \%$ in 1994 as a result of the serious crisis of 1992-1994. Unemployment reached its highest levels for many years in 1995, but from then on it decreased year after year. However, temporariness continued to grow over the years, 
with employers taking advantage of the new types of contract. It is very revealing that of all the new jobs created in 1994, 96.6\% were temporary. The effects of temporariness were already visible because they involved more workplace accidents, less training and therefore lower productivity. Instead of taking on one worker for four months, many companies would take on four workers for one month each.

The Conservative's Party (PP), which had won the previous year's elections, had the support of the Spanish Confederation of Employers' Organizations (CEOE), the Spanish Confederation of Small and Medium-Sized Companies (CEPIME), the Workers' Committees (CC.OO.) and the General Workers' Union (UGT) to go ahead with the third reform. Employment policy was conditional upon the initiatives coming out of the European Union (EU), specifically from what was known as the "European Employment Strategy", in which work was starting to be linked with social cohesion. The first step was the 1997 Treaty of Amsterdam and its endorsement months later at the European Summit in Luxembourg, where the strategy of significantly reducing unemployment on a European scale in five years was established. The countries committed themselves to following a multilateral framework of vigilance that included a joint annual report on employment and carrying out national action plans drawn up in advance by member states. Common aims and targets concentrated on four points: the fight against unemployment and dropping out of school; clear, stable, reliable rules for company creation and management; the modernization of work organization and flexibility and the drawing-up of contracts that could be adapted to different types of work; and the fight against inequality between men and women. The Lisbon Extraordinary European Council in 2000 introduced the concept of social cohesion with its proposal to create a dynamic, highly technological economy that would also have a strong degree of cohesion.

On this occasion the reform focused on the fight against temporariness, given that unemployment had been decreasing for a number of years. The "new business launch" contract was eliminated and a "contract for the promotion of indefinite employment" created, which involved lower compensation in cases of unfair dismissal for objective reasons and aimed to provide incentives for temporary contracts to be made indefinite. It was also aimed at those who had the most difficulty in gaining entry to the labour market: young unemployed people between 18 and 29, the long-term unemployed who had been registered as seeking work for at least a year, the over-45s and the disabled. The reform intended to use the economic recovery to improve the way the labour market functioned so as to address the problems of unemployment, job insecurity and high staff turnover. Unemployment would continue its downward trend over the next few years but temporariness would continue to rise, the bulk of it to be found in "temporary", "construction or services" and "part-time” contracts (Kugler, Jimeno, \& Hernanz, 2003).

Social cohesion returned to the scene thanks to the effects of temporariness in the fourth reform of the labour market in the shape of the 12/2001 and 45/2002 Acts, at a time when the unemployment rate was at one of its lowest points, $10.49 \%$, although temporariness remained high at $31.70 \%$. The purpose of this reform was to prolong the measures adopted in the previous reform. Its most notable action was to eliminate the "part-time" temporary contract that was included in other types of contract. This time the incentives given for the featured “employment promotion" contract would apply to unemployed women between 16 and 45, unemployed women taken on in jobs or professions with low numbers of female workers, the unemployed who had been registered continuously as seeking work for 6 months or more, and the unemployed aged 55 to 65. A social integration contract was created for carrying out construction and services of general interest for the public administration as a means of gaining work experience. Incentives were extended to cover all unemployed women between 16 and 45 , and the allowance added to the incentive when a full-time contract was given to an unemployed woman was prolonged.

A general strike was called in 2002 to protest against the government's reform of unemployment protection and employment promotion measures. The reform was introduced by the 56/2003 Act, which amended the Employment Act, establishing what were known as employment policies defined as a set of decisions adopted by the state and the autonomous communities that were aimed at developing programmes and measures seeking to bring about full employment. The purpose of these policies was to narrow the divide between the European labour market and the Spanish labour market, acting selectively in favour of particular groups and situations such as female employment, long-term unemployment, the disabled, the workforce's lack of training, geographical and spatial mobility, the imbalances between the different labour markets, the excessive temporariness in employment and the low rate of participation by the public employment services in finding people jobs. They were divided into active and passive policies. Active policies included all guidance, employment and training programmes and measures aimed at improving the chances of the unemployed accessing employment in the labour 
market either as employees or self-employed, adapting workers' training and recycling for employment, and other measures aimed at fomenting a spirit of business and social economy. Passive policies were those aimed at support services for the unemployed.

The penultimate reform introduced by the 43/2006 Act was preceded by the 2004 "Declaration for Social Dialogue on Competitiveness, Stable Employment and Social Cohesion”, endorsed by the CEOE, CEPIME, UGT, CC.OO and the President of the Government. In line with European employment strategy directives, its purpose was to tackle the two biggest problems afflicting the labour market in Spain since the transition: the low rate of employment (insufficient volume of employment) and the high degree of temporariness. A limit was set for the size of temporary contract chains, whereby only two or more temporary contracts signed by the same company with the same worker for the same job were allowed. In addition, when an employee had worked in the same company for more than 24 months in a period of 30 months, he or she would automatically be made permanent. Measures were also set up to boost active employment policies and the capacity of the national employment system to act and improve worker protection as a response to the lack of jobs. Incentives to take on staff covered women in general, women taken on within 24 months of their date of confinement or adoption, women going back to work after 5 years outside the labour market, the over-45s, young people aged 16 to 30 , people who had been unemployed continuously for 6 months, and people with a disability. Improvements were also made to the Wage Guarantee Fund from which workers were paid if their company went bankrupt, taking charge of redundancies. Social integration contracts were eliminated (Gorelli, 2007).

In 2006 unemployment fell to 8.51\%, a figure unheard of since the 1970s. Immigration at the time stood at $4,482,568$ people representing $10 \%$ of the population as a whole, with 820,000 work permits having been issued to foreigners, a figure three times that of only three years earlier and almost eight times the number issued ten years earlier. This cheap, compliant workforce made the labour market more flexible because the immigrants took on unskilled jobs that the Spanish did not deign or did not want to do-construction, agricultural work, domestic service, caring for the elderly. This was of great benefit to women, who in 2006 had an employment rate of $47.95 \%$, nine points higher than in 1996, an increase of almost 3 million more working women, which helped to close the gap between them and their European counterparts. Indeed the labour market achieved record figures, but structurally this led employers to use the work factor very intensively to the detriment of productivity (Carreras \& Tafunell, 2010).

The latest reform was contained in the 35/2010 Act, motivated by the world financial and economic crisis that has had such a huge effect in Spain since 2008, with unemployment rising by no less than 9 points (from $11.3 \%$ to $20.1 \%$ in 2010) and temporariness remaining at 30\%. This has reinforced the theory that employment is sensitive to the economic cycle in that it increases intensively in times of growth but is destroyed with the same intensity in downturns. According to the Act, this could be explained by the high levels of temporary work, the low levels of internal flexibility in companies, the limited capacity of active employment policies and continuing discrimination in the labour market, especially as regards the employment of women, the disabled and the older unemployed.

On this occasion it was a case of adapting the labour market to the Sustainable Economy Strategy set up by the government to speed the renewal of the production model begun in December 2009. It assumed the need for a change of social and production model given the volatility of the jobs created since the start of the decade and focused on a great many interconnected aspects within the system of labour relations: job creation, flexibility in the contractual framework, the revitalization of the labour market's mediation mechanisms and the imminent reform of collective bargaining. The traditional action to improve the figures for temporariness materialized in making it cheaper to get rid of permanent staff and more expensive to get rid of temporary staff. Temporary contract chains were prohibited and the "open-ended employment promotion” contract strengthened and given expanded scope to cover workers trapped in temporariness. Incentives were given for taking on untrained, unemployed young people under 30 and older workers who were long-term unemployed. The reform also included the introduction of the Austrian model that incorporated the setting up before 1 January 2012 of a capitalization fund for workers to bring together severance payments and allowances for geographical mobility, training activities and retirement.

Since 2008 the effects of the international crisis on the Spanish labour market have been traumatic given that financial problems have been combined with the property bubble, the lack of competitiveness, high levels of unemployment and precarious jobs. Over the last decade the loss of competitiveness compared to the EU has fluctuated between $4.3 \%$ if export prices are taken into account and $12 \%$ if labour costs are taken into account. If 
compared to the OECD, these figures rise to $7.5 \%$ and $28 \%$ respectively. Social dialogue and the renewal of agreements have been affected, and the agreement on wage rises, signed for the first time in 2002 on the basis of increasing wages in line with European Central Bank's inflation target and a percentage of productivity gains, is now being called into question by employers. The problem lies in the fact that Spanish growth came about in the boom years with a considerable increase in employment while wages in general were depreciating. Also, the creation of jobs was concentrated in the most unskilled sectors (construction and services) and among the immigrant population, who were more willing to accept lower wages. The economic crisis has highlighted the Spanish labour market's inability to find a solution to a crisis of this size, destroying thousands of jobs and causing urgent measures to be adopted to reform it (the 35/2010 Act).

\section{Employment Data from the Labour Force Survey}

The evolution of the labour market in Spain (Figure 1) can be measured using data from various sources such as the National Institute of Statistics (INE), the Ministry of Work and Social Affairs and the National Institute of Employment (INEM). These organizations provide the most important statistics like the Labour Force Survey, the Employment Situation Report and the numbers of unemployed registered with the INEM. The main source for figures on unemployment, the working population, active population and temporariness is the Labour Force Survey, which constantly collects data for publication every quarter and is mainly concerned with households. It has been run since 1964 by the INE in accordance with guidelines laid down by the International Labour Organization. Its main purpose is to obtain data on the labour force and its various categories (the working, the unemployed) as well as the population outside the labour market (the non-working). The initial sample is 65,000 households a quarter, which in practice boils down to effective interviews with around 60,000 households, equivalent to about 180,000 individuals. The unemployed are defined as those aged 16 or over who during the week in question did not have a job but were available for work and actively seeking employment. This category also includes those who have found work but not yet started and who still meet the first two conditions (Rodríguez, 2008; Toharia, 2006).

International comparison with other EU countries shows just how seriously two of the basic magnitudes of the Spanish labour market have deteriorated. There is an extremely high rate of unemployment, in many cases twice the size of other EU countries, and an extreme level of temporariness (25.4\%) —in 2006 it was 34\%—which means that, of the $80 \%$ of the active population that has a job, a quarter of them are temporary (Figure 2). However, this situation is not the same for all workers; young people, women and less skilled workers are the worst affected. Moreover, in 2008, the most recent figures held by Eurostat, Spain spent the not insignificant sum of $2.517 \%$ of GDP on labour market policies, a rate exceeded only by Belgium. The extremely complicated situation with which we are familiar today could derive from the fact that the reforms carried out in line with employment policy have erred by taking a piecemeal approach and being of limited scope and sometimes contradictory due to the urgency of the times in which they were designed: the financial crisis of the unemployment benefit system in 1992, the large-scale destruction of jobs between 1992 and 1994, and nominal convergence

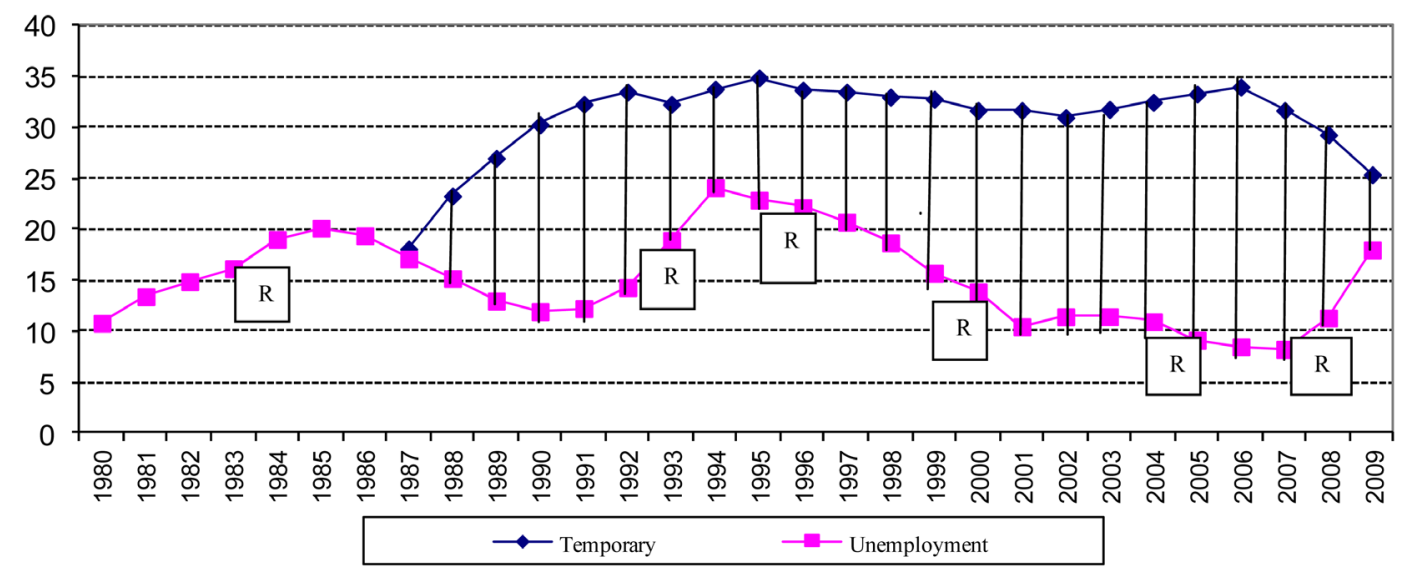

Figure 1. Evolution of the rates of unemployment and temporality 1980-2009. Labour statistics. Ministerio de Empleo y Seguridad Social. www.empleo.gob.es 


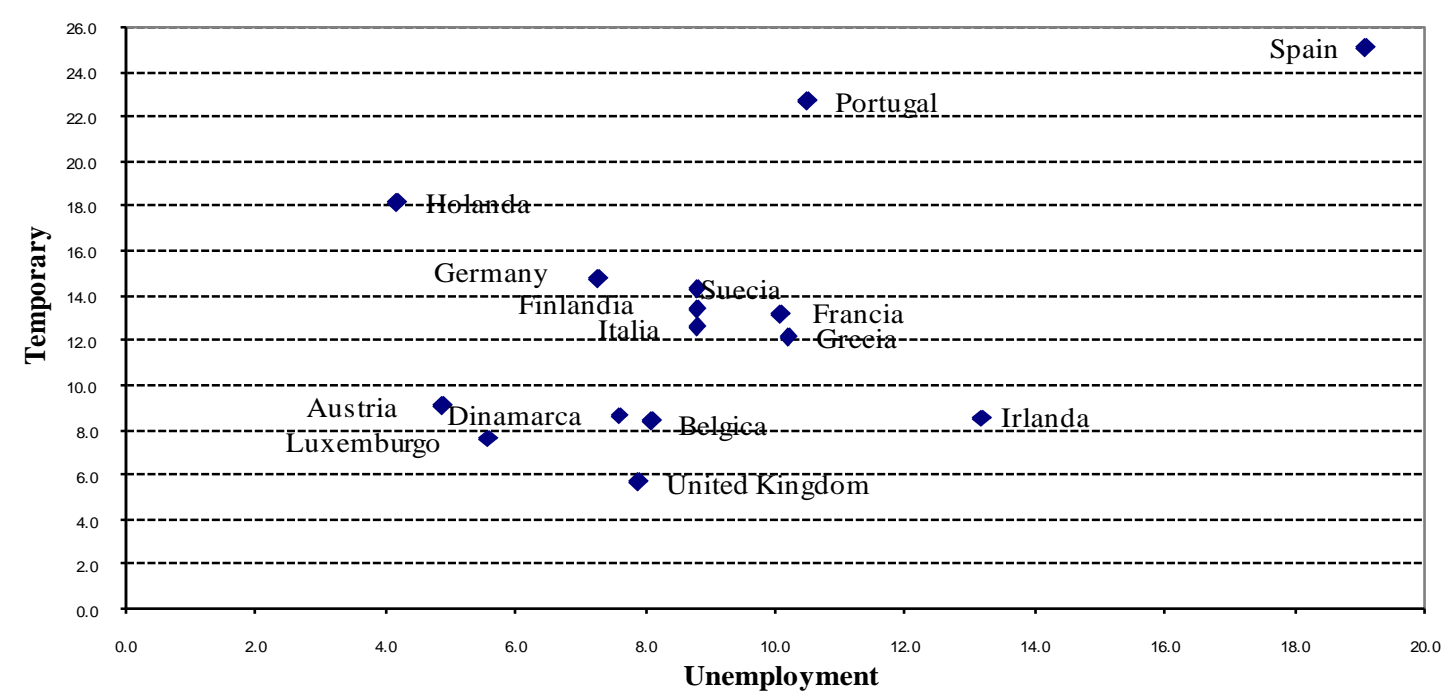

Figure 2. Relationship between the rate of temporary contracts in the European Union and the harmonised unemployment rate in 2010. Eurostat (2011). European economic statistic. Epp.eurostat.ec.europa.eu/tgm/print

with the EU in 1997. As far as temporariness is concerned, much of the growth in this area over recent years can be traced back to public administrations, especially local ones.

\section{Social Cohesion through the Care Market}

The care market, which is based on social protection and given this name in order to achieve a certain parallel with the labour market because in the end it also consists of supply and demand transactions, plays a subsidiary role in social cohesion, offsetting the detrimental effects of the labour market in areas such old age, sickness, accidents and death while at the same time inserting into society the most disadvantaged collectives such as the elderly, widows, the sick, orphans, the disabled and the unemployed - whether or not they are contributors-who cannot benefit from the earnings the labour market provides (Maxwell, 1996). This safety net is what is known as "social security" and its origins in Spain can be traced back to 1963 and the Social Security Framework Act, which unified all the various social insurance schemes that existed at the time and eliminated, for example, businesses in this field that operated for profit. 1967 saw the first Social Security Act, which was not financed via the national budget because it did not need to be. Being a new system with many contributors and few beneficiaries, it produced surpluses in the form of funds and capital transfers that were allocated to professional training and the construction of housing and hospitals. The Act underwent successive amendments in 1972 and especially in 1974 with a new Social Security Act that would remain in force for twenty years. In 1977 social security was separated from the Ministry of Work to become part of the Ministry of Health and Social Security.

The modern pillars of social cohesion through social security date back to the Constitution of 1978 and the Moncloa Pacts of 1981. The first of these established the criterion that Spain was a democratic social state that recognized aims such as family protection, income redistribution, full employment and care for the physically disabled and the elderly. In short it specifically recognized the right of every Spaniard to the same social security regardless of whether or not they were active workers. The second contained an agreement with the trade unions to increase social spending in return for their acceptance of labour market deregulation and wage restraint. This meant the creation of a social security system that was universal and redistributive inspired by the Beveridge model in the UK, gradually abandoning the Bismarck model and guaranteeing the same level of protection for the population as a whole regardless of employment categories or business sectors. It also laid the main foundations that in the context of a democratic social state under the rule of law would guarantee a defence against all the big risks of living in a society. These steps made it possible for decisions to be adopted in the 1980s that were crucial for social cohesion from the point of view of social protection. As happened with the labour market, the hard-fought agreements of those years would leave their mark on the following decades in the shape of farreaching initiatives in pensions and health that together would absorb a high proportion of spending on social protection. 


\subsection{Care Market from ESSPROS}

The European System of Integrated Social Protection Statistics (ESSPROS) used by the EU statistics office Eurostat includes internationally standardized measures to make comparisons possible, which also means a great effort by all members to work in the same way. The core system includes basic items known as functions-sickness/healthcare, disability, old age, survivors, family/children, unemployment, housing and social exclusion-and comprises periodic or one-off transfers to households, in cash or in kind, intended to relieve them from the financial burden of a number of risks or needs. Thus social protection is made up of all those actions by public or private bodies aimed at relieving the burden that a pre-determined series of risks and needs represents for households and individuals, as long as no simultaneous and reciprocal agreement exists. It also includes any expense involved in covering the financial burdens which, for individuals or households, are represented by the appearance or existence of certain risks, contingencies or needs, in so far as the expense involves the intervention of a third party and does not have a simultaneous equivalent counter-action on the part of the beneficiary. Social protection benefits include periodic and one-off payments, benefits in kind and social contributions given to relieve people of a series of specific needs or risks (Eurostat, 1996).

In the case of pensions, it must be taken into account that under the amendments of the 24/1997 Social Security System Consolidation and Rationalization Act, pensions that were previously listed as disability pensions became known as temporary incapacity pensions, and when the recipients reached age 65 they became known as retirement pensions. In December 1997 approximately 900,000 permanent incapacity pensions for beneficiaries aged 65 and over were considered to be retirement pensions. In 2001 another reform was introduced whereby non-contributory disability pensions for beneficiaries aged 65 and over were also added to retirement pensions, which explains the number of pensions awarded. The evolution of the eight ESSPROS items between 19802008 (this being the latest year available) in Spain, measured as a percentage of GDP in what is known as the "effort", reflects the importance of each of the variables considered. Comparing Spain's spending both per capita and as a percentage of GDP with the other countries of the EU (Figure 3), the conclusion is that the country is in a very precarious position.

Very noticeable is the low spending on what is known as "intensity", measured as the spending per inhabitant expressed in purchasing power standards (PPS), an indicator that reliably represents the purchasing power equivalent of the social benefits awarded in the various countries, taking into account that there may be big differences in prices between them (Figure 4). Also noticeable is the low spending as a proportion of GDP, exceeded by countries with very small populations that do not need to allocate large portions of their GDP in order to nevertheless have high "per capita” spending. The graph also supports Lindert's theory (2004) according to which those European countries with the highest wealth index are the ones that on average spend the most on social protection, which leads one to think that there is a clear relationship between these two variables—and not

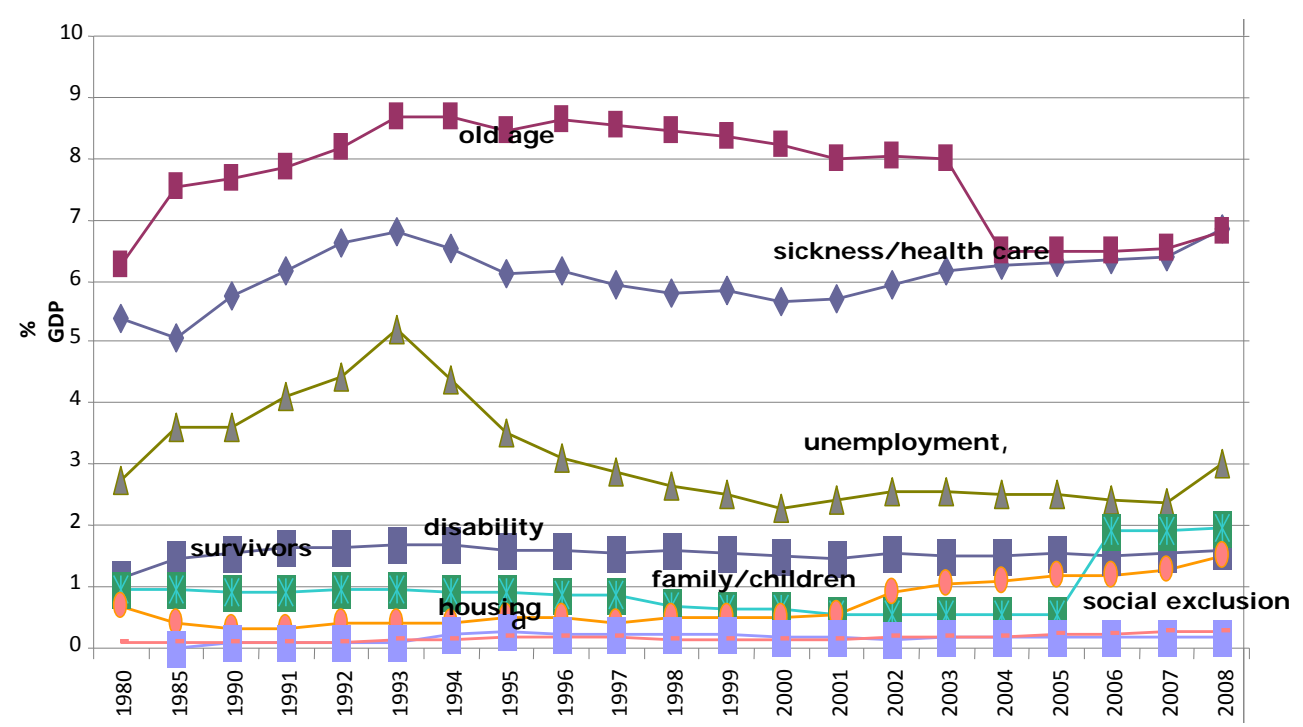

Figure 3. Evolution of variables ESSPROS 1980-2008. Eurostat, Expenditure on social protection. Luxembourg, 2011. http://nui.epp.eurostat.ec.europa.eu/nui/print.do 


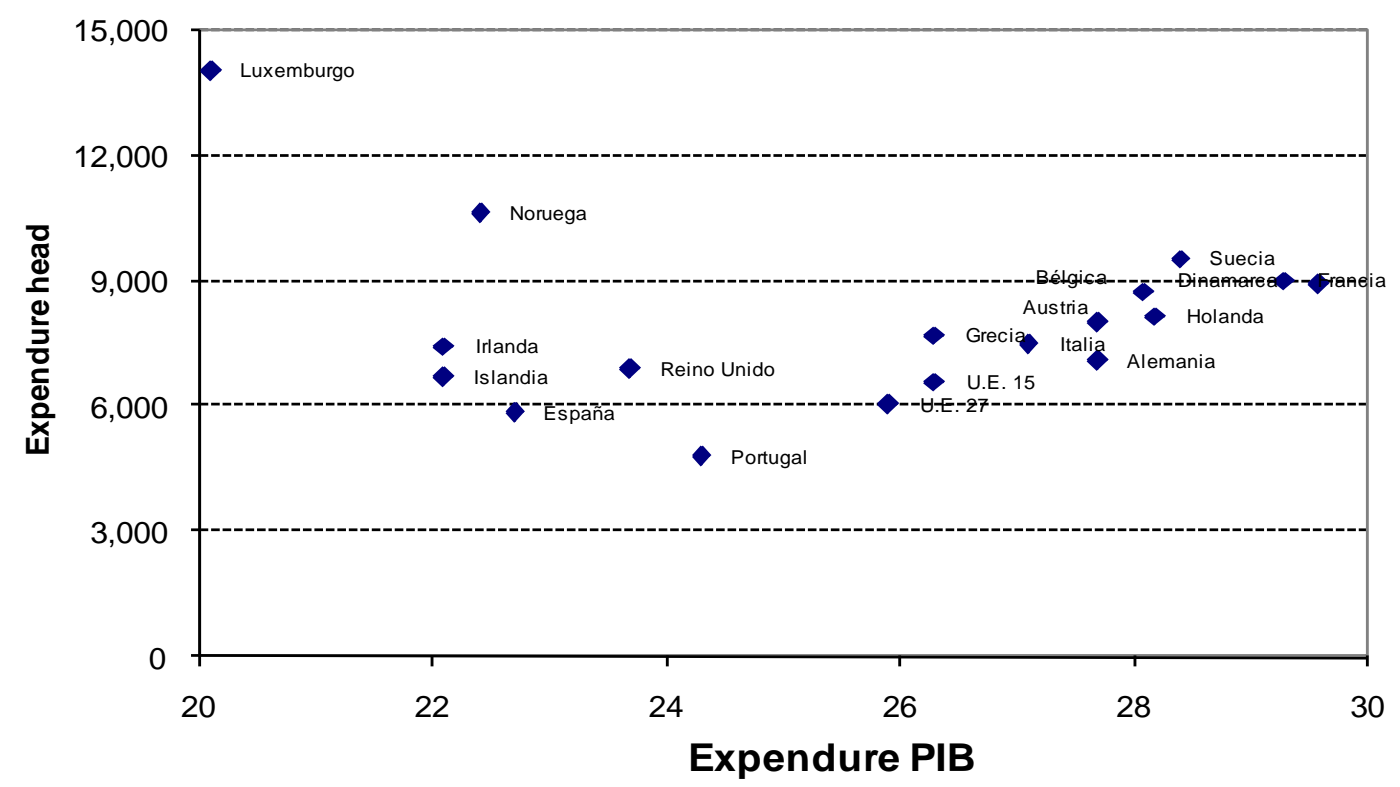

Figure 4. Expenditure of social protection, in terms of ESSPROS, in relation to the gross domestic product to market in the EU (\%). 2007. Eurostat, Expenditure on social protection. Luxembourg, 2011. http://nui.epp.eurostat.ec.europa.eu/nui/print.do

always due to the wealth-protection cause and effect but also in the direction protection-wealth, as argued by a number of authors in their analyses of the Nordic countries (Navarro, 2007).

\subsection{Pensions}

Pensions have been a major element in social cohesion in Spain because they involve intergenerational solidarity between adults and the elderly. A huge transformation in pensions (for the retired, disabled, widows, orphans, family members and others) took place between 1980 and 1983, when the average amount paid increased from 15,161 to 24,782 pesetas and a record coverage figure of 5 million people was reached with expenditure of 9\% of GDP (Barrada, 1999). Progress was also made with help for the unemployed, with 1982 seeing 105,997 people being included at benefit level, to be joined two years later by another 192,301 seasonal agricultural workers. Bad figures for the labour market unfortunately cut short this institutional assistance and, along with retirement pensions, which had been spiralling out of control since 1976 due to the strategy of converting redundancies into early retirements, gave rise to the first far-reaching reform consisting of urgent measures to rationalize the way social security provided protection (the 26/1985 Act). The importance of this law was similar to that used to reform the labour market in 1984 because it sought to eliminate the bad habits that had characterized earlier procedures while at the same time laying the foundations for its financing, which henceforth would be via the national budget. The foundations were also laid for future actions based on the effects of a series of variables such as the population pyramid, involving the entry of larger cohorts of pensioners with higher incomes - the substitution effect-greater life expectancy after age 65, minimum pensions and pension revaluation. Entitlement to a retirement pension increased from 10 to 15 years' contributions and the period taken into account to calculate the amount rose from 2 years to 8 . It was guaranteed that pensions would be increased in line with the RPI and that state pensions would be improved.

Various reforms were carried out from 1985 to 1990, aimed at overcoming fraud and rationalizing the proportionality between length of time contributed and amount received. The lowest pensions were increased while simultaneously the time spent waiting for the pension to be paid was decreased. The social security budget became part of the general national budget in 1988. In 1990, at a time of low unemployment, the Socialist government took an important step towards social cohesion by introducing universal protection in the shape of noncontributory benefits to cover situations of old age and disability not considered in the contributory model, eliminating all traces of a discretionary or welfare nature by providing an economic income, medical and pharmaceutical assistance and social services. This made it possible for many elderly or disabled people who for various 
reasons had not contributed to have a pension regardless of their social security status, thereby giving the Spanish system a dual character in which contributory and non-contributory benefits complemented each other. It also established that social protection was based not so much on a professional criterion of contributions whereby only workers were covered, but on a system according to residence whereby those who lived within the territory were protected. In other words the universality of benefits was assured because they no longer depended exclusively on contributions but were provided by all the citizens as a whole.

Hence the way social cohesion was shaped from this direction drew progressively further away from the contributory scheme and clearly ever nearer the concept of taxation in which the existence of contributions did not provide the right to demand a certain level of benefits, nor for the amount of contributions to have an effect on their level or content. In the case of retirement pensions, however, these being a contributory benefit, there was nothing strange about the fact that their award, content and characteristics could be influenced to a greater or lesser extent by the beneficiary's contribution record, i.e. the amount of the benefit depended on the existence and amount of contributions made. The social protection system leaned towards having a marked dual character, i.e. a contributory branch complemented by a welfare or non-contributory branch, and this was enough for Spain to enter, albeit timidly, into the British or Atlantic model (non-contributory and universal), also known as the welfare model. Nevertheless, the bulk of social protection continued to be based on the German model, which gave priority to the concept of social insurance, characterized by its compulsory nature, tripartite funding, public management and legal determination of its beneficiaries (Carpio \& Domingo, 1996).

In spite of everything, the reforms were not sufficient because the factors mentioned earlier continued to be problems: number of pensioners, percentage of GDP allocated to pensions, minimum pensions, revaluation of retirement pensions in line with growth of RPI, ratio of contributors to pensioners, life expectancy after age 65 and the substitution effect. Hence the agreements reached in the 2006 Social Dialogue echoed the recommendations of both the EU and the International Monetary Fund as regards the system's sustainability in the face of demographic evolution. The result of this was the 40/2007 Social Security Measures Act, which raised the effective number of years of contributions for calculating pensions to 15 and extended the age limit for partial retirement to 61 as long as the worker had at least 6 years' seniority in the company and a 30-year contribution record. The criteria for entitlement to disability pensions were also rationalized.

\subsection{Health}

Inequality in health is a very significant aspect for social cohesion because it involves differences in life expectancy, sickness and death between different social strata (Kawachi, 2005; Kronenfeld, 2010). Indeed there are numerous studies linking inequality with healthcare assistance that reflect the chances that people have of completely recovering from an illness depending on their sex, age, social class and ethnic group (Kronenfeld, 2009; Walton, 2009; Zambrana \& Carter, 2010). Certain strata have a higher incidence of chronic illnesses such as diabetes and hypertension, a higher mortality rate and worse results for general health (Ministerio de Sanidad and Política Social, 2009, 2010). Healthcare is vital for social cohesion because it means solidarity between the healthy and the sick, the upper classes and the lower (Webster, 2011; Zambrana \& Carter, 2010).

Since its modern beginnings under democracy, health in Spain has undergone fewer sudden changes than pensions. Indeed there have been only small reforms since the first law, the 1986 Health Act, was presented by the Socialist minister Ernest Lluch. This brought universal coverage regardless of contributions and decentralization through the transfer of healthcare to the autonomous communities, coordinating them via an inter-territorial council under the Ministry of Health. Hence the constitutional mandate of Articles 43 and 49 and also Title VIII were fulfilled, giving the autonomous communities wide-ranging competencies in health matters, while at the same time Article 38.1a of the 1974 Social Security Act was being developed to include healthcare in cases of maternity, common industrial diseases and accidents, whether or not in connection with work, as part of protective action in the area of social security. This law established that civil servants could choose between the national health system and Muface, whose healthcare was available through insurance companies.

An extremely important event for the national health system came about in 2000 via the 4/2000 Act establishing the rights and freedoms of foreign residents in Spain. This allowed them access to the social security system and gave them the right to healthcare under the same conditions as Spaniards as long as they were registered on the electoral roll in the council area where they normally resided (Article 12). 2002 saw the completion of transfers to the autonomous communities, and in 2003 the next law was passed, oddly named the Cohesion and Quality Act by the People’s Party, in an attempt to update the 1986 Act by rationalizing the transfers to the 
autonomous communities and eliminating the differences that were being generated between them by giving new competencies in the area of cohesion to the national health system's Inter-territorial Council, which had been created under the previous Act and was to hold meetings at least four times a year when convened by the President or requested by a third of the members (Moreno, 2007; Rey, 2006).

This law led to the introduction of the individual healthcare card, which included information as to the holder's identity and his or her rights as regards pharmaceutical assistance. In 2004 the way costs had evolved meant that the first Conference of Presidents dealt with the subject of financing, with the government accepting responsibility for the increase. Healthcare data for Spain are quite significant as regards social cohesion: health accounts for $6.5 \%$ of GDP and 35\% of total spending by the autonomous communities and is the biggest employer in Spain, providing jobs for 616,232 qualified professional health workers in 2008 (213,000 doctors, 250,000 nurses and 61,000 pharmacists). The problem of financing healthcare led in 2008 to the setting up of an initiative to create a national charter aimed at finding points of agreement between all the health administrations to guarantee and improve the quality and sustainability of the national health system.

\section{Conclusion}

The evolution of social cohesion in Spain 1980-2010 has been conditioned exogenously by the competitiveness of the markets at an international level. Indeed one could say that the continuous changes in the interrelationship of forces in the division of work on a global level have meant a reorientation of living conditions in Spain dependent on the relationship between imports and exports. The great raw materials crisis of the late 1970s had a huge effect on the Spanish labour market in the following years. The foundations for social cohesion in Spain were laid in the 1980s from the perspective of work with the Workers' Statute and the Employment Act. Higher unemployment after 1980 brought about the first big reform of the labour market in 1985 with the novel solution of exchanging unemployment for temporariness, as had been tried out in other European countries.

In real life this meant the stratification of the active population by age, sex and skill, giving rise to a privileged nucleus of permanent workers at the cost of another nucleus of temporary workers which found itself on the sidelines with the prospect of severance payments that were low or non-existent as opposed to high and inaccessible for permanent workers. Since then the Workers' Statute has been amended on seven occasions, sometimes in periods of crisis and sometimes in periods of boom, and this has almost always involved a set of changes to contract regulations and incentive policies whose new structure was fairly similar to the old: new types of temporary or indefinite contracts or the elimination of old ones, extending their coverage, extending or reducing their duration, increases or reductions in social security contributions, reductions or increases in severance payments, clarification of the causes of severance and a long "mix and match" list of collectives that have benefited from consecutive incentives, now linear, previously proportional.

As far as the other side of the coin is concerned-what is known as the care market, dependent on contributions deriving from the labour market and state funding-in the 1980s this had its historical roots in the 1963 Social Security Framework Act, amended in 1967, 1972 and 1974 (the final amendment remaining valid for 20 years). The 1980s were fundamental because they paved the way for unemployment with benefit and growth in pensions. The first modification, though not of great importance, came about in a context of generalized crisis in 1985 when the conditions affecting pensions and unemployment welfare were modified. However, the good figures for later years led to a very significant event, the 1990 Non-Contributory Benefits Act, which brought acknowledgement of the universality of pensions and changed the situation by including the financing of welfare in taxation.

\section{References}

Barrada, A. (1999). El gasto público de bienestar social en España. Madrid: Fundación BBV.

Bentolila, M. (1997). Las decisiones judiciales sobre despidos en España: Una perspectiva económica. Cuadernos de Información Económica, 128-129, 170-179.

Carpio, M., \& Domingo, E. (1996). Presente y futuro de las pensiones en España. Madrid: Encuentro.

Carreras, A., \& Tafunell, X. (2010). Historia económica de la España contemporánea (1789-2009). Barcelona: Crítica.

Connolly, H., Marino S., \& Lucio, M. (2014). Trade Union Renewal and the Challenges of Representation: Strategies towards Migrant and Ethnic Minority Workers in the Netherlands, Spain and the United Kingdom. European Journal of Industrial Relations, 20, 5- 20. http://dx.doi.org/10.1177/0959680113516848 
Dolado, J., \& Jimeno, J. (2004). Contratación temporal y costes de despido en España: Lecciones para el futuro desde la perspectiva del pasado. Documento de trabajo 48/2004. Madrid: Fundación Alternativas.

Dolado, J., García, C., \& Jimeno, J. F. (2002). Drawing Lessons from the Boom of Temporary Jobs in Spain. The Economic Journal, 112, F270-F 295. http://dx.doi.org/10.1111/1468-0297.00048

Easterly, W., Ritzer, J., \& Woolcock, M. (2006). Social Cohesion, Institutions and Growth. Economics \& Politics, 18, 103-120. http://dx.doi.org/10.1111/j.1468-0343.2006.00165.x

European Council (2008). Well Being for All. Concepts and Tools for Social Cohesion. Trends in Social Cohesion, No. 20, Strasbourg: Council of Europe Publishing.

Gorelli, J. (2007). La reforma laboral española de 2006. Revista Internacional del Trabajo, 126, 128-132.

Grupo de Trabajo de Análisis del Gasto sanitario (2005). Informe.

Hernández de Frutos, T. (2003). Estructuras de cohesión social: Escenarios de futuro y tendencias de cambio. In J. Tezanos, Compilado, Tendencias en desvertebración social y en políticas de solidaridad (pp. 45-69). Madrid: Sistema.

Hernández de Frutos, T. (2009). Crecimiento y crisis del sistema industrial español. De los planes de estabilización a los distritos marshalianos. Sistema, 212, 31-55.

Kawachi, J. (2005). Why the United States Is Not Number One in health. In J. Morone, \& L. Jacobs (Eds.), Healthy, Wealth and Fair (pp. 19-36). New York: Oxford University Press.

Kronenfeld, J. (2009). Social Sources of Disparities in Health and Health Care: An Introduction to the Volume. Research in the Sociology of Health Care, 27, 3-17. http://dx.doi.org/10.1108/S0275-4959(2009)0000027003

Kronenfeld, J. (2010). Social Factors Leading to Differences in Health and Health Care: The Influence of Factors such as Race/Ethnicity, Geography, and Gender. Research in the Sociology of Health Care, 28, 3-17. http://dx.doi.org/10.1108/S0275-4959(2010)0000028003

Kugler, A., Jimeno, J. F., \& Hernanz, V. (2003). Employment Consequences of Restrictive Employment Policies: Evidences from Spanish Labour Market Reforms. Working Paper 2003-2014, Madrid: FEDEA.

Lindert, P. (2004). Growing Public, Social Spending and Economic Growth since the Eighteeth Century. Cambridge: Cambridge University Press.

Maxwell, J. (1996). Social Dimension of Economic Growth. Eric John Hanson Memorial Lecture Serie. Vol. VIII. Edmonton: Univesity of Alberta.

Ministerio de Sanidad and Política Social (2009). Informe: Análisis de situación para la elaboración de una propuesta de políticas e interven- ciones para reducir las desigualdades sociales en salud en España. Madrid: Ministerio de Sanidad.

Ministerio de Sanidad and Política Social (2010). Informe: Avanzando hacia la equidad. Madrid: Ministerio de Sanidad.

Molina, O. (2014). Self-Regulation and the State in Industrial Relations in Southern Europe: Back to the Future. European Journal of Industrial Relations, 20, 21-36. http://dx.doi.org/10.1177/0959680113516404

Moreno, F. J. (2007). Del sistema sanitario de la seguridad social al sistema nacional de salud descentralizado. In J. L. Tortuero, Compilado, Cien Años de Protección Social en España (pp. 101-135). Madrid: Ministerio de Trabajo y Asuntos Sociales.

Navarro, V. (2007). El Estado de Bienestar en España y sus déficits sociales. Vitoria: Federación de Cajas de Ahorros Vasco-Navarras.

OECD (1997). International Conference "Sustainable Cities: Linking Competitiveness with Social Cohesion”. October, Montreal: OECD.

Rey, J. (2006). Algunos comentarios sobre la conferencia de presidentes autonómicos y el futuro del sistema nacional de salud. Revista de Administración Sanitaria, 4, 323-339.

Rodríguez, J. C. (2008). La información estadística sobre el mercado de trabajo en España. Revista del Ministerio de Trabajo y Asuntos Sociales, 71, 67-98.

Sánchez, E., \& Delicado, C. (2007). Temporalidad en el empleo y mercado de trabajo para los jóvenes en España. Madrid: Consejo de la Juventud en España.

Segura, J., Durán, F., Toharia, L., \& Bentolila, J. (1991). Análisis de la contratación temporal en España. Madrid: Ministerio de Trabajo y Servicios Sociales.

Shire, K., Schönauer, A., Valverde, M., \& Mottweiler, H. (2009). Collective Bargaining and Temporary Contracts in Call Centre Employment in Austria, Germany and Spain. European Journal of Industrial Relations, 15, 437-456. http://dx.doi.org/10.1177/0959680109344370

Stoleroff, A. (2013). Employment Relations and Unions in Public Administration in Portugal and Spain: From Reform to Austerity. European Journal of Industrial Relations, 19, 309-322. http://dx.doi.org/10.1177/0959680113505033 
Toharia, L. (2006). El desempleo en España. In V. Navarro, Compilado, La situación social en España (pp. 181-212). Madrid: Biblioteca Nueva.

Walton, E. (2009). Residential Segregation and Birth Weight among Racial and Ethnic Minorities in the United States. Journal of Health and Social Behaviour, 50, 427-442. http://dx.doi.org/10.1177/002214650905000404

Webster, N. (2011). Medicare Knowledge and Health Service Utilization among Older Adults. Research in the Sociology of Health Care, 29, 273-297. http://dx.doi.org/10.1108/S0275-4959(2011)0000029014

Zambrana, R., \& Carter, O. (2010). Role of Acculturation Research in Advancing Science and Practice in Reducing Health Care Disparities among Latinos. American Journal of Public Health, 100, 18-23. http://dx.doi.org/10.2105/AJPH.2008.138826 
Scientific Research Publishing (SCIRP) is one of the largest Open Access journal publishers. It is currently publishing more than 200 open access, online, peer-reviewed journals covering a wide range of academic disciplines. SCIRP serves the worldwide academic communities and contributes to the progress and application of science with its publication.

Other selected journals from SCIRP are listed as below. Submit your manuscript to us via either submit@scirp.org or Online Submission Portal.
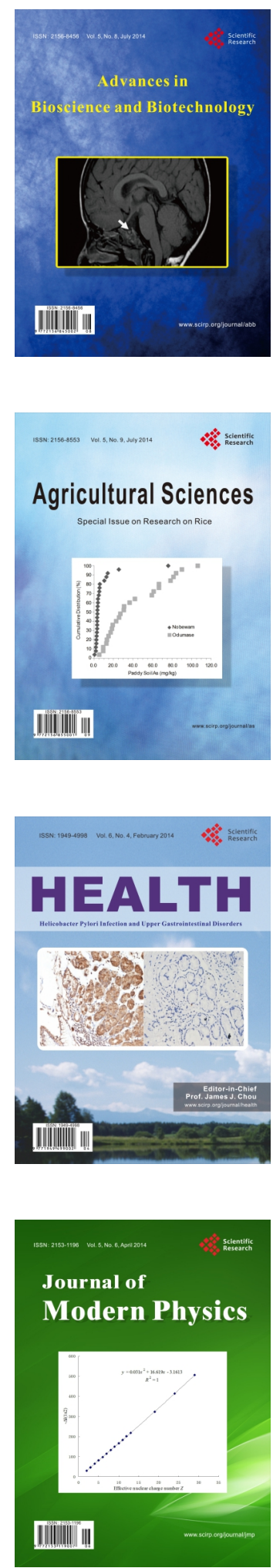
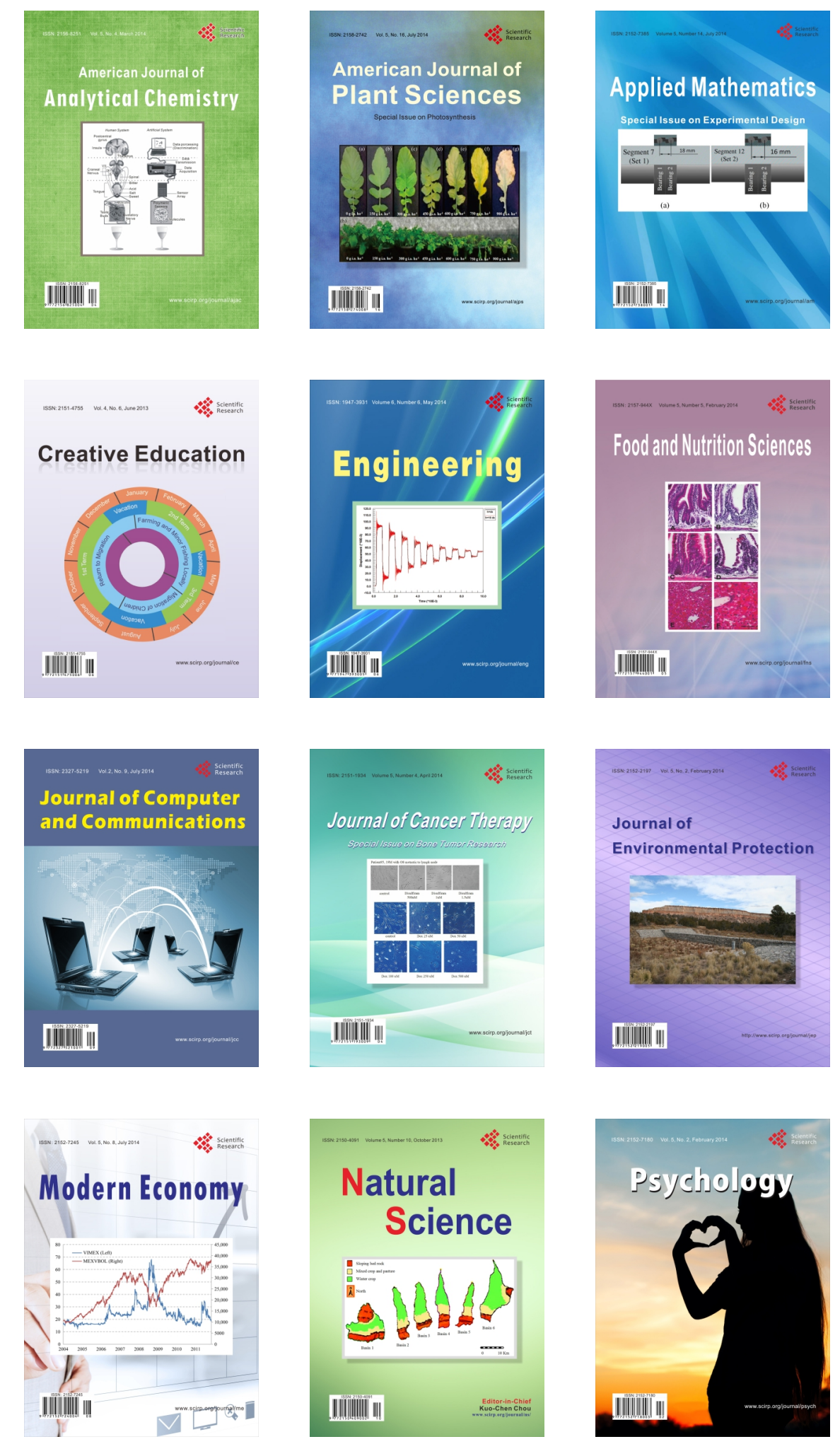